\title{
Biocorrosion and biofouling of metals and alloys of industrial usage. Present state of the art at the beginning of the new millennium
}

\author{
H. A. Videla*
}

Abstract

An overview on the present state of the art on Biocorrosion and Biofouling of metals and alloys of industrial usage is offered on the basis of the experience gathered in our laboratory over 25 years of research. The key concepts to understand the main effects of microorganisms on metal decay are briefly discussed. New trends in monitoring and control strategies to mitigate biocorrosion and biofouling deleterious effects are also described. Several relevant cases of biocorrosion studied by our research group are successively described: i) biocorrosion of aluminum and its alloys by fungal contaminants of jet fuels; ii) Sulfate-reducing bacteria SRB induced corrosion of steel; iii) biocorrosion and biofouling interactions in the marine environment; iv) monitoring strategies for assessing biocorrosion in industrial water systems; v) microbial inhibition of corrosion; vi) use and limitations of electrochemical techniques for evaluating biocorrosion effects. The future perspective of the field is made considering the potential of innovative techniques in microscopy (environmental scanning electron microscopy, confocal scanning laser microscopy, atomic force microscopy), new spectroscopical techniques used for the study of corrosion products and biofilms (energy dispersion X-ray analysis, X-ray photoelectron spectroscopy, electron microprobe analysis) and electrochemistry (electrochemical impedance spectroscopy, electrochemical noise analysis).

Keywords Biocorrosion. Biofouling. Microorganisms. Biofilms. SRB.

\section{Biocorrosión y biofouling de metales y aleaciones de uso industrial. Estado actual del conocimiento en el inicio del nuevo milenio}

Resumen

\begin{abstract}
Se ofrece una revisión del estado actual del conocimiento sobre Biocorrosión y Biofouling de metales y aleaciones de uso industrial basada en la experiencia desarrollada en nuestro laboratorio durante 25 años de investigación en el área. Se discuten brevemente los conceptos clave necesarios para entender los principales efectos de los microorganismos en el deterioro de los metales. También se presentan las nuevas tendencias seguidas para el monitoreo y las nuevas estrategias de control para mitigar los efectos perjudiciales de la biocorrosión y el biofouling. Varios casos significativos de biocorrosión que fueron estudiados por nuestro grupo de investigación se describen en forma sucesiva: i) la biocorrosión del aluminio y aleaciones por contaminantes fúngicos de turbocombustibles; ii) la corrosión del acero inducida por bacterias sulfatoreductoras (BSR); iii) las interacciones entre la biocorrosión y el biofouling en medio marino; iv) las estrategias de monitoreo para el seguimiento de la biocorrosión en sistemas de aguas industriales; v) la inhibición microbiana de la corrosión; vi) el uso y las limitaciones de las técnicas electroquímicas para la evaluación de la bicorrosión. Las perspectivas futuras en el área se analizan considerando el potencial de las nuevas técnicas de microscopía (microscopía de barrido de electrones ambiental, microscopía confocal de rayos laser, microscopía de fuerza atómica), técnicas de análisis elemental aplicadas al estudio de superficies (análisis por dispersión de energía de rayos X, análisis por difracción de rayos X, espectroscopía de fotoemisión electrónica de rayos $\mathrm{X}$, microsonda electrónica) y electroquímicas (espectroscopía de impedancia electroquímica y análisis de ruido electroquímico).
\end{abstract}

Palabras clave Biocorrosión. Biofouling. Microorganismos. Biofilms. Bacterias sulfatoreductoras (BSR).

(*) Department of Chemistry. College of Pure Sciences. University of La Plata. Argentina. 


\section{INTRODUCTION}

Microorganisms influence corrosion by changing the electrochemical conditions at the metal/ solution interface. These changes may have different effects, ranging from the induction of localized corrosion, through a change in the rate of general corrosion, to corrosion inhibition ${ }^{[1]}$. Any biological effect that either facilitates or impedes one of the anodic or cathodic reactions of the corrosion process, or permanently separates anodic and cathodic sites, will increase corrosion. For instance, stimulation of the anodic reaction by acidic metabolites or the cathodic reaction by microbial production of a cathodic reactant like hydrogen sulfide, the breakdown of protective films or the increase in conductivity of the liquid environment will enhance corrosion.

Although the electrochemical nature of corrosion remains valid for microbial corrosion, the participation of the microorganisms in the process induces several unique features, mainly the modification of the metal/solution interface by biofilm formation. Biofilms affect the interaction between metal surfaces and the environment, not only in biodeterioration processes like corrosion, but also in several biotechnological processess applied to materials recovery and handling ${ }^{[2]}$. Thus, the key to the alteration of conditions at a metal surface, and hence the enhancement or inhibition of corrosion is the formation of a biofilm ${ }^{[3]}$. This can be considered as a gel containing $95 \%$ or more water, made of a matrix of exopolysaccharidic substances (EPS) in which microbial cells, and inorganic detritus are suspended ${ }^{[4]}$.

Biofilm formation is the result of an accumulation process - not necessarily uniform in time or space ${ }^{[5]}$ that starts immediately after metal immersion in the aqueous environment. A thin film (approximately 20-80 $\mathrm{nm}$ thick), due to the deposition of inorganic ions and high relative molecular mass organic compounds, is formed in a first stage. This initial film is able to alter the electrostatic charges and wettability of the metal surface facilitating its further colonization by bacteria. In a short time, (minutes or hours according to the aqueous environment where the metal is immersed), microbial growth and EPS production results in the development of a biofilm. This biofilm is a dynamic system and the different transport processes and chemical reactions occurring at the biofouled interface will take place from now on, through the biofilm thickness ${ }^{[6]}$.

Microbial colonization of metal surfaces drastically changes the classical concept of the electrical interface commonly used in inorganic corrosion. Important changes in the type and concentration of ions, $\mathrm{pH}$ values and oxidationreduction potential are induced by the biofilm, altering the passive or active behavior of the metallic substratum and its corrosion products, as well as the electrochemical parameters used for assessing corrosion rates ${ }^{[7]}$.

Simultaneously with the biological changes that lead to biofilm accumulation, a sequence of inorganic changes takes place at the metal surface immediately after its immersion in an aggressive aqueous medium. This sequence involves the process of metal dissolution and corrosion product formation. Both biological and inorganic processes occur within the same time period, but following opposite directions at the metal/solution interface. Whereas corrosion and corrosion product accumulation occur from the metal surface towards the solution, biofilm formation is the result of accumulation processes directed from the bulk towards the metal surface. Thus, a very active interaction between the corrosion product layers and the biofilms can be expected. The consequent corrosion behavior of the metal will vary according to the degree of this reciprocal interaction and a concept of a new biologically conditioned interface must be kept in mind ${ }^{[8]}$. The approach for a sound interpretation of any microbial corrosion case must then be interdisciplinary, and include a thorough process analysis combined with well defined microbiological and electrochemical methodologies ${ }^{[9]}$.

Biocorrosion has been focusing increasing attention from different research areas in the last two decades as an answer to the demand of a wide variety of industries. Fortunately an increasing intellectual and technical cross-fertilization of ideas between researchers from different disciplines like microbiology, electrochemistry and materials science has allowed a considerable improvement in the understanding of biocorrosion to be reached.

On the basis of the expertise gathered in our laboratory over 25 years of research in the field a brief overview on several relevant practical cases will be made. 
Biocorrosion and biofouling of metals and alloys of industrial usage. Present state of the art at the begining of the new millennium H. A. VIDELA

\section{BIOCORROSION OF ALUMINUM AND ITS ALLOYS BY FUNGAL CONTAMINANTS OF JET FUELS}

Microbial contamination of hydrocarbon fuels is the main cause of serious problems concerning the quality of maintenance of the product, as well as the corrosion of metals used during the processes of extraction, production, distribution, and storage of the fuel. Microoganisms usually present in droplets or thin films are sufficient to allow microbial growth and the development of biocorrosion. Because of the electrochemical nature of biocorrosion an aqueous environment is also required.

Since the end of the 70's several of our publications have been devoted to elucidate the mechanisms affecting the whole biocorrosion process ${ }^{[10-13]}$. Thus, the following effects have been successively studied and reported:

i) the interrelationship between the electrochemical and biological variables ${ }^{[10}$ and 11$]$

ii) the use of electrochemical techniques and parameters to assess and differentiate microbial activities ${ }^{[12]}$

iii) the analysis of the physicochemical composition of the medium in relation to corrosion $^{[13 \text { and } 14]}$

iv) the importance of adhesion processes due to fungal attachment to the metal surface ${ }^{[15]}$.

Mechanisms to explain the action of fungal contaminants of jet fuels in corrosion can be briefly summarized as follows: a) Local increase in the proton concentration, derived from organic acidic metabolites; b) Greater oxidizing characteristics of the medium favoring pitting attack; c) Metabolite production decreasing the surface energy of the interface passive film/electrolyte; d) Microbial adhesion processes enhancing metal dissolution, and e) Microbial uptake of corrosion inhibitors (mainly nitrates and phosphates).

A simplified scheme to illustrate the all these mechanisms has been reported ${ }^{[16]}$.

\section{SULFATE-REDUCING BACTERIA (SRB) INDUCED CORROSION OF STEEL}

Biocorrosion of carbon steel in anaerobic environments involving the presence of SRB has been the focus of most biocorrosion research. Starting with the cathodic depolarization theory (CDT) of von Wolzogen Kuhr \& Van der
Vlugt $^{[17]}$, a copious list of papers and reviews on the anaerobic corrosion of iron has been published $^{[18 \text { and } 20]}$. Bacterial biofilms may develop anaerobic regions, even in aerobic bulk water environments ${ }^{[2]}$, thus allowing SRB a very favorable environment for growth. The final result of these processes within biofilms is to produce a wide variey of sites on the metal surface that are markedly different from neighboring sites from a physicochemical standpoint, thus facilitating the initiation of localized corrosion processes.

As the localized corrosion and breakdown process is strongly dependent of several experimental factors such as the type and concentration of aggressive anions present in the medium and the passivating film characteristics, the effect of sulphur anions has been studied in a series of laboratory experiments using alkaline ${ }^{[21]}$ and neutral buffered ${ }^{[22]}$ solutions as well as SRB cultures in saline medis ${ }^{[23]}$ under well defined experimental conditions. Taking into account the results of these studies, a bioelectrochemical interpretation of the biocorrosion process of carbon steel in anaerobic environments may be summarized as follows ${ }^{[24]}$ :

i) biogenic sulfides effects on carbon steel passivity breakdown is similar to that of abiotic sulfides. The characteristics and intensity of sulfide effects on the corrosion behavior of carbon steel is narrowly related with the nature of the passive film already present on the metal surface;

ii) in neutral media sulfide ions lead to the formation of a poorly protective film of mackinawite;

iii) the anodic breakdown of passivity would be the first stage of the corrosion process. Thus, the role of SRB may be indirect through the production of aggressive species either as final (sulfides, bisulfides or hydrogen sulfide) or intermediate metabolic compounds (thiosulphates, polythionates). Physicochemical characteristiscs of the liquid environment $(\mathrm{pH}$, ionic composition, oxygen levels) can modify the SRB effects which could eventually change from corrosive to passivating;

iv) cathodic depolarization effects attributed to SRB hydrogenase activity or to iron sulfide films would be developed later than passivity breakdown while corrosion process is in progress; v) the action of biogenic sulfides 
can be enhanced by other aggressive anions already present in the environment (e.g. chlorides) ${ }^{[25]}$ or through microbial consortia within adhered biofilms on the metal surface $^{[26]}$.

Further studies developed in our laboratory ${ }^{[27-29]}$ allowed us to conclude that SRB influenced corrosion of steel is markedly affected by the nature and the structure of the sulfide films produced during the metal dissolution. The environmental characteristics of the metal/biofilm/ medium interface and its surroundings $(\mathrm{pH}$, ionic composition, oxygen levels, EPS distribution) control the chemical and physical nature of corrosion product layers and may change their effects on the metal behaviour from corrosive to protective. In marine environments, the impact of sulphur compounds on corrosion is enhanced by other aggressive anions, such as the widely distributed chlorides, already present in the medium.

The entrance of oxygen into the anaerobic environment accelerates corrosion rate, mainly through a change in the chemical nature of iron sulfides and elemental sulphur production. Both chemical species can provide additional cathodic reactants to the corrosion process, acting as electron carriers between the metal and the oxic interface within the biofilm.

The differences between biotic and abiotic media containing identical levels of corrosive compounds (i.e. iron sulfides) can be mainly attributed to the presence of extracellular polymers and to the heterogeneities created at the metal surface by the formation of a biofilm. In addition, the physicochemical parameters of the corrosion product layers may change in the absence or a presence of a biofilm, rendering these layers either protective or corrosive. This may explain the observed differences in corrosion behaviour of steel between abiotic and biotic environments with respect not only to a localized pitting, but also the hydrogen attack manifested as embrittlement and crack growth.

\section{BIOCORROSION AND BIOFOULING INTERACTIONS IN THE MARINE ENVIRONMENT}

Abiotic corrosion processes probably influence the rate, extent and distribution of colonizing microbial species as well as the chemical composition and physical properties of the resulting biofilm. It was found ${ }^{[30]}$ that the corrosion behavior of the metallic substratum influences the rate of formation and distribution of biofilms in flowing seawater. Non-uniform corrosion promotes patchy adsorption of the microorganisms whereas a patchy biofilm enhances diffrential aeration effects like those observed on biofouled stainless steel and coppernickel samples exposed to flowing seawater ${ }^{[2]}$. At cathodic sites of corroding surfaces there is an increase of $\mathrm{pH}$ and electrolyte concentration. Conversely, a decrease in $\mathrm{pH}$ and electrolyte concentration is produced at anodic sites, both effects influencing bacterial adsorption processes.

Another aspect related to biofilm-corrosion product interactions is the spalling or sloughing of corrosion products associated with biofilms by the EPS mucilague ${ }^{[31]}$ as it was found in copper-based alloys exposed to seawater.

Biofilm/corrosion product interactions in the marine environment ${ }^{[32]}$ can affect the corrosion behavior of metals and alloys by :

- hindering the transport of chemical species necessary for the passivation of the metal surface

- facilitating the removal of protective layers as biofilm detachment occurs

- forming differential aeration cells as a result of a patchy distribution of the biofilm

- altering gradients of oxygen, $\mathrm{pH}$ and other components of the bulk liquid

\section{MONITORING STRATEGIES FOR ASSESSING BIOCORROSION IN INDUSTRIAL WATER SYSTEMS}

Monitoring programs for biofouling and biocorrosion have been mainly focused in the assessment of planktonic populations in water samples, and generalized corrosion by using corrosion coupons or some kind of resistance or polarization resistance probes.

The main objections to these monitoring programs are:

i) the planktonic population does not properly reflect the type and number of organisms living in the biofilm and causing biodeterioration problems;

ii) susceptibility of planktonic microorganisms to antimicrobial agents markedly differs from that of sessile microorganisms within the biofilm, mainly because of the protective 
action of their EPS. Thus, the monitoring methods adopted must provide information of well-established biofilms like those developed in system water.

From the corrosion side, the electrical resistance method is appropriate for indicating a change in the general corrosion rate, but the results are difficult to interpret in the presence of localized corrosion like pitting, the most frequent form of attack found in biocorrosion cases ${ }^{[33]}$. If biofilms or localized corrosion are present, the polarization resistance will reveal that something is happening, but may not give an accurate measure of the corrosion rate. Only the use of any of these techniques jointly with other electrochemical methods or parameters assessing localized corrosion hazard can provide valuable data for monitoring the deleterious effects of biocorrosion and biofouling.

Owing to the variables of dissimilar nature involved in biofouling and biocorrosion, an effective monitoring program, either for the laboratory or the field, must necessarily supply information on water quality, corrosive attack, sessile and planktonic bacteria populations, biofilms characteristics, and chemical composition of inorganic and biological deposits $^{[34]}$.

Sampling devices for monitoring biocorrosion and biofilms can be simultaneously used to assess corrosion attack after the removal of biological and inorganic deposits, giving a wider and more useful information. Sampling devices fall into two main types: a) directly implanted and, b) sidestream implanted. Metal coupons, generally made with the same structural material of the system, present a known surface area, to enable an accurate count of sessile bacteria per square $\mathrm{cm}$. after biofilm detachment. Coupons are mounted in holding assemblies which are inserted in the pipework of the laboratory or industrial system.

Two practical cases of monitoring biocorrosion in industrial waters developed in our laboratory are described in the literature.

Chemical industry cooling water systems. A monitoring program based on laboratory and field measurements for assessing biodeterioration on mild steel and stainless steel in recirculating cooling water systems has been reported ${ }^{[35]}$. This program was based on: i) water quality control; ii) corrosion monitoring in the field (weight loss and linear polarization probe); iii) laboratory corrosion tests (polarization techniques and corrosion potential vs. time measurements), and iv) use of a multipurpose sampling device that allows monitoring of sessile populations, biofilms, corrosive attack, morphology and intensity, and biological and inorganic deposits analysis. The side stream sampling device (RENAprobe ${ }^{\mathrm{TM}}$ ) allows realiable biofilm and corrosion sampling without introducing important modifications in the system.

Oilfield water injection system. Among the several factors related to biocorrosion hazard in secondary oil recovery operations are:

i) velocity, temperature, oxygen level and redox potential of the injection water;

ii) chemical composition, $\mathrm{pH}$ amount of organic matter and depth of pumping of the injection water

iii) effectivenes of the biocide to gain access to the biofilms. Taking into account these factors a multiple monitoring program for biofouling and biocorrosion was implemented in an oild field in Argentina ${ }^{[36]}$. The goal of the program was to perform a rapid evaluation of the bacteriological status of the system, and to implement an effective biocide treatment for sessile bacteria.

One of the classic concepts for maintaining an industrial system free of biodeteriorating effects is "to keep the system clean". Although this is a very difficult task to accomplish in practice, there are several general methods that can be used. These methods can be broadly classified in:

i) physical

ii) chemical. Among the former, flushing is perhaps the most simple, although of limited efficacy. A special case is the use of flushing supported by cleaners or jointly with chemical agents that induce biofilm detachment. Abrasive or non-abrasive sponge balls are frequently employed in the industry. The former could present problems related with protective passive films that can be damaged, and the second is not very effective with thick biofilms.

With reference to chemical methods, the most common approach for controlling biofouling problems in industrial water systems, is the use of biocides. These substances can be either oxidizing or non-oxidizing toxicants. Chlorine, ozone and bromine are three typical oxidizing agents of industrial use. Non-oxidizing biocides are claimed to be more effective than oxidizing biocides for an 
overall control of algae, fungi, and bacteria. They have a greater persistence and many of them are $\mathrm{pH}$ independent. Often a combination of oxidizing and non-oxidizing biocides or of two non-oxidizing biocides is used to optimize microbiological control of industrial water systems. Typical biocides of the second type are formaldehyde, glutaraldehyde, isothiazolones and quaternary ammonia compounds.

Increasing legislative requirements and the necessity for greater environmental acceptability, have contributed to restrict the use of some traditional biocides and to develop either new compounds or carefully selected blends of existing biocides.

Taking into account environmental concerns, the use of ozone for different types of industrial water systems, presents several advantages with respect to other biocides ${ }^{[37]}$. The unique combination of high toxicity of ozone during treatment, with no toxicant discharge, could make ozone the biocide of choice for the present decade, if an appropriate balance between positive effects and costs is reached. Several publications from our laboratory on ozone biocidal action on sessile and planktonic bacteria, its mechanisms of disinfection and the optimization of its use can be found in the literature ${ }^{[37 \text { and } 38]}$

\section{MICROBIAL INHIBITION OF CORROSION}

Corrosion inhibiton is the slow down of the corrosion reaction usually performed by substances which, when added in small amounts to an environment, decrease the rate of attack by this environment on a metal (corrosion inhibitors). Microorganisms are able to drastically change the electrochemical conditions at the metal/solution interface. These changes can range from the induction or acceleration of corrosion to corrosion inhibition. There are several examples of microbial effects that could enhance corrosion:

i) stimulation of the anodic reaction by acidic metabolites or the cathodic reaction by microbial production of a new alternative cathodic reactant (e.g. $\mathrm{H}_{2} \mathrm{~S}$ );

ii) the microbial breakdown of protective films or

iii) the increase in conductivity of the liquid environment. However, microbial effects causing corrosion inhibition has been seldomly mentioned in the literature ${ }^{[39]}$.
Microorganisms can aid to achieve corrosion inhibition according to some of the following mechanisms:

i) neutralizing the action of corrosive substances present in the environment;

ii) forming protective films or stabilizing a preexisting protective film on a metal;

iii) inducing a decrease in the medium corrosiveness.

As general key features of this subject it can be summarized the following points ${ }^{[40]}$ :

- Biocorrosion and its counter-process, microbial inhibition of corrosion, are rarely linked to a single mechanism of to a single species of microorganisms.

- Either the corrosive or the inhibitory action of bacteria are developed at biofilmed metal surfaces where complex biofilm/ protective films interactions occur. Biological activity leads to important changes in the type and concentrations of ions, $\mathrm{pH}$ and oxygen levels inducing significant variations in the physical and chemical characteristics of the environment as well as in the electrochemical parameters used to measure the corrosion rate.

- The main mechanisms of corrosion inhibition by bacteria are always linked to a marked modification of the environmental conditions at the metal/solution interface by biological activity.

- Microbial corrosion inhibition is frequently accomplished through: i) a decrease in the cathodic rate by microbial consumption of a cathodic reactant (e.g. oxygen consumption by respiratory activity); ii) decreasing the medium aggressiveness in restricted areas of the metal solution interface (e.g. by neutralizing acidity); iii) providing or stabilizing protective films on the metal (e.g. biofilm exopolymers with metal binding capacity).

- It must be stressed that in practical situations, the inhibitory action of bacteria can be reversed to a corrosive action whithin bacterial consortia structured in biofilm thickness.

A proper understanding of the identity and role of microbial contaminants in the specific environment of a metal surface may be used to induce corrosion inhibition by bacteria as a useful 
Biocorrosion and biofouling of metals and alloys of industrial usage. Present state of the art at the begining of the new millennium H. A. VIDELA

tool to prevent frequent biodeterioration effects encountered in practice.

\section{USE AND LIMITATIONS OF ELECTROCHEMICAL TECHNIQUES FOR EVALUATING BIOCORROSION EFFECTS}

The basic concepts of electrochemical corrosion are valid in biocorrosion and could be used to interpret the acceleration of the corrosion process by microorganisms in different aqueous media both under anaerobic or aerobic conditions.

Biocorrosion is rarely interpreted by a single mechanism or seldomly caused by single species of microoganisms ${ }^{[7]}$. Hence, it is important to be cautious in the interpretation of data supplied by electrochemical methods. Oftenly, these techniques have been used in complex media where the characteristics and properties of passive films are not well understood. For instance, the presence of complex deposits of corrosion products, metabolites and EPS may dramatically reduce the usefulness of some electrochemical results. Moreover, it has to be kept in mind that microbial colonization of passive metals can drastically change their resistance to breakdown by changing locally the type and concentration of ions, $\mathrm{pH}$ values, oxygen gradients and inhibitor levels. These changes should result in important alterations in the electrochemical behavior of the metal and in the electrochemical parameters measured in laboratory experiments. In conclusion, whenever electrochemical techniques will be used for the evaluation of biocorrosion, the actual condition of the metal surface must be considered ${ }^{[9]}$.

In classical electrochemical studies, the interface between a metal and the surrounding electrolyte has been characterized by a certain distribution of electrical charges giving rise to the so-called electrical double layer ${ }^{[8]}$. The knowledge about the structure of the double layer at the metal/solution interface is mainly based on experimental data obtained with the dropping mercury electrode. Thus, the behavior of the interface between mercury and several aqueous electrolyte solutions could be considered approximately equal to that of an ideally polarizable interface. However, at the light of the present knowledge on biocorrosion It can be easily inferred that this behavior is markedly different from that corresponding to the complex metal/solution interface associated with biocorrosion ${ }^{[9]}$. Consequently, electrochemical concepts used for inorganic corrosion analysis will have to be adapted to the characteristics of the biologically conditioned interface.

A detailed description of the electrochemical methods for evaluating biocorrosion is out of the scope of this paper. A wide variety of electrochemical techniques such as corrosion and redox potentials measurements, Tafel and potentiodynamic polarization, linear polarization and electrical resistance probes, and several modern electrochemical techniques like alternating current methods or electrochemical noise have been recently reviewed by several authors in relation to their use in biocorrosion evaluation $^{[33,41 \text { and } 42]}$.

A careful use of several electrochemical concepts and methods should be coupled when possible, with visual inspection, microscopy, innovative surface analysis techniques and a sound microbiological analysis to reach an adequate characterization of the causative microorganisms, their interactions and the effects of their metabolic activities and products on corrosion.

\section{FUTURE PERSPECTIVES IN BIOCORROSION AND BIOFOULING OF METALS AND ALLOYS OF INDUSTRIAL USAGE}

Important improvements in analytical, microbiological, electrochemical and microscopical techniques and instrumentation have allowed the development of new methods for laboratory and field assessment of biocorrosion in industrial systems.

Chemical analysis within the biofilm by means of microsensors is one of the most exciting advances in instrumentation ${ }^{[43]}$. Biofilm systems have been considered to be diffusion limited ${ }^{[4]}$. As a consequence, chemical conditions at the surface and within biofilms can vary dramatically over a distance of a few micrometers. Thus, the information obtained from bulk water analysis has a limited value and must be closely analysed before any conclusions are drawn about the behavior of the metal/solution interface. Direct measurements inside biofilms are restricted by:

i) the small thickness of the biofilm;

ii) the diffusion limitation of concentration profiles across the biofilm;

iii) the heterogeneous nature of the biofilm. The latter aspect is specially important not only in relation to microbial coverage of the surface but also with respect to biocorrosion. 
An example of microsensor technology applied to evaluate vertical profiles of chemical species in biofilm systems has been recently reported ${ }^{[45]}$. Equally important tools for the study of biofilm structure are the fiber optic microprobe or optrode used for finding the location of the biofilm/bulk water interface, and the mapping of electric fields ${ }^{[46]}$ by means of the scanning vibrating microprobe (SVM).

Advanced microbiological techniques such as DNA probes have recently been applied to biocorrosion and biofouling research ${ }^{[47]}$. Although these techniques are restricted to the laboratory at present, their joint utilization with microbiological field measurements can be highly useful for monitoring biocorrosion.

Recent developments in microscopy such as the environmental scanning electron microscope (ESEM), the confocal laser microscope (CSL) and the atomic force microscope (AFM) permit biofilm observation in real time and without intoducing distortion of the samples. There is an increasing number of references using these innovative technologies in recent biocorrosion literature ${ }^{[48-50]}$.

A combination of CSL and microelectrode techniques allowed correlation of oxygen concentration profiles with biofilm structure ${ }^{[51]}$. CSL facilitates the visualization of biofilm structures by eliminating the interference arising from out of focus objects ${ }^{[52]}$. Observations performed under flow conditions and using physiologically active biofilms, provided information to construct a new conceptual model of biofilm structure.

On the corrosion side, new electrochemical test methods for the study of localized corrosion phenomena in biocorrosion analysis and monitoring have been presented ${ }^{[53]}$.

\section{REFERENCES}

[1] H.A. VIDELA, Corrosion/96, NACE International, Houston, TX, paper No. 223, 1996.

[2] H.A. Videla and W.G. Characklis, Int. Biodeterior. Biodegr. 29 (1992) 195-212.

[3] R.G.J. EdYveAn and H.A. Videla, Interdisc. Sci. Rev. 16 (1991) 267-282.

[4] G.G. GeEsey, Am. Soc. Microbiol. News 48 (1982) 9.

[5] W.G. Characklis and K.C. Marshall, Biofilms, Characklis, W.G. and Marshall, K.C. (eds.), John Wiley and Sons Ltd, New York, 1990, p. 3.

[6] W.G. Characklis, Biotech. Bioeng. 23 (1981) 1923-1960.
[7] H.A. VIDELA, Structure and Function of Biofilms, Characklis, W.G. and Wilderer, P.A. (eds.), John Wiley \& Sons, Chichester, U.K., 1989, pp. 301-320.

[8] H.A. VIDELA, Biodeterioration and Biodegradation 8, Rossmoore H.W. (ed.), Elsevier Applied Science, London, 1991, p. 63.

[9] H.A. VIDELA, Bioextraction and Biodeterioration of Metals, Gaylarde, C.C. and Videla, H.A. (eds.) Cambridge University Press, Cambridge, UK, 1995, p. 85.

[10] M.F.L. De Mele, R.C. Salvarezza and H.A. Videla, Int. Biodet. Bull. 15 (1979) 39-44.

[11] R.C. Salvarezza, M.F.L. De Mele and H.A. Videla, Int. Biodet. Bull. 15 (1979) 125-132.

[12] R.C. Salvarezza, M.F.L. De Mele and H.A. Videla, Br. Corros. J. 16 (1981)162-168.

[13] R.C. Salvarezza and H.A. Videla, Biodeterioration 6, Barry, S., Houghton, D.R., Llewellyn, G.C. and O' Rear, C.E. (eds.), CAB International Mycological Institute, London, UK, 1986, p. 212.

[14] R.C. Salvarezza, M.F.L. De Mele and H.A. Videla, Corrosion 39 (1983) 26-32

[15] H.A. VIDELA, Biologically Induced Corrosion, Dexter, S.C. (ed.), NACE-8, Houston, TX, NACE, 1986, p. 215.

[16] H.A. Videla, Manual of Biocorrosion, Chapter 7, Boca Raton, Florida: CRC Lewis Publishers, 1996, p. 201.

[17] G.A.H. von Wolzogen KüHR and L.R. van Der Vlugt, Water (den Haag) 18 (1934) 147 (Translation in Corrosion 17 (1961) 293)

[18] J.D.A. Miller, Microbial Biodeterioration, Rose, A.D. (ed.), Academic Press, New York, 1981, p. 149.

[19] R.C. Salvarezza and H.A. Videla, Corrosion 36 (1980) 550-554.

[20] G. Gragnolino and O.H. Tuovinen, Int. Biodeterior. 20 (1984) 9-26.

[21] R.C. Salvarezza, H.A. Videla and A.J. Arvía, Corros. Sci. 22 (1982) 815-829.

[22] R.C. Salvarezza, H.A. Videla and A.J. Arvía, Corros. Sci. 23 (1983) 717-732.

[23] H.A. VIDELA, Biologically Induced Corrosion, Dexter, S.C. (ed.), NACE-8, Houston, TX, 1986, p. 162.

[24] H.A. VIDELA, Biodeterior. 7, Houghton, D.R., Smith, R.N. and Eggins, H.O.W. (eds.), Elsevier Applied Science, London, 1988, p. 359.

[25] C.A. Acosta, R.C. Salvarezza, H.A. Videla and A.J. ARVÍA, Electrochemical behaviour of mild steel in sulfide and chloride containing solutions, Passivity of Metals and Semiconductors, Froment, M. (ed.), 1984, pp. 387-392.

[26] J.W. COSterton and G.G. Geesey, Biologically Induced Corrosion, Dexter, S.C. (ed.), NACE-8, Houston, TX, NACE, 1986, p. 223.

[27] H.A. Videla, C.L. Swords, M.F.L. de Mele, R.G. Edyvean, P. Watkins and I.B. BeECH, Corrosion/98, NACE International, Houston, TX, paper No. 289, 1998.

[28] H.A. Videla, R.G. Edyvean, C.L. Swords, M.F.L. DE MELE and I.B. BEECH, Corrosion/99, NACE International, Houston, TX, paper No. 163, 1999.

[29] H.A. VIDELA, Biofouling 15 (2000) 37-47.

[30] H.A. Videla, M.F.L. DE MELE and G.J. BRanKEVICH, Corrosion/87, NACE International, Houston, TX, paper No. 365, 1987.

[31] H.A. Videla, M.F.L. DE Mele and G.J. BrankEVICH, Corrosion/89, NACE International, Houston, TX, paper No. 291, 1989. 
Biocorrosion and biofouling of metals and alloys of industrial usage. Present state of the art at the begining of the new millennium H. A. VIDELA

[32] H.A. Videla, Manual of Biocorrosion, Chapter 3, Boca Raton, Florida: CRC Lewis Publishers, 1996, p. 47.

[33] S.C. Dexter, D.J. Duquette, O.W. Siebert and H.A. VIDELA, Corrosion/89, NACE International, Houston, TX, paper No. 616, 1989.

[34] H.A. Videla, Manual of Biocorrosion, Chapter 6, Boca Raton, Florida: CRC Lewis Publishers, 1996, p. 137.

[35] H.A. Videla, F. Bianchi, M.M.S. Freitas, C.G. Canales and J.F. WILKES, Microbiological Influenced Corrosion Testing, Kerns, J. R. and Little, B.J., eds., ASTM Publications STP 1232, American Society for Testing and Materials, Philadelphia, PA, 1994, p. 128.

[36] H.A. Videla, P.S. Guiamet, O.R. Pardini, E. Echarte, D. Trujlllo and M.M.S. Freitas, Corrosion/91, NACE International, Houston, TX, paper No. 103, 1991.

[37] H.A. Videla, M.R. Viera, P.S. GuiAmeT and M.F.L DE MELE, Corrosion/99, NACE International, Houston, TX, paper No. 186, 1999.

[38] P.S. Guiamet, S.G. Gómez de Saravia and H.A. Videla, Inter. Biodet. Biodegr. 43 (1999) 31-35.

[39] H.A. VIDELA, Reviews on Corrosion Inhibitor Science and Technology, Vol 2, Raman, A. and Labine, P., eds., Chapter IX, NACE International, Houston, TX, 1996, p. 1.

[40] H.A. Videla, Manual of Biocorrosion, Chapter 5, Boca Raton, Florida: CRC Lewis Publishers, 1996, p. 121.

[41] D.J. DuQuetTE, Argentine-USA Workshop on Biodeterioration (CONICET-NSF), Videla, H.A. ed., Aquatec Quimica S.A., Sao Paulo, Brazil, 1996, p. 15.

[42] F. MAnsfeld and B.J. LitTle, Corrosion/90, NACE International, Houston, TX, paper No. 108, 1990.

[43] Z. LEWANDOWSKI, Biofouling and Biocorrosion in Industrial Water Systems, Geesey, G.G., Lewandowski, Z. and
Flemming, H.C. (eds.), Lewis Publishers, Boca Raton, FL, 1994, p. 175.

[44] W.G. Characklis, Biofilms, Characklis, W.G. and Marshall, K.C. (eds.), John Wiley \& Sons, New York, 1990, p. 195.

[45] Z. Lewandowski, T. Funk, F. Roe and B. Little, Microbiologically Influenced Corrosion Testing, Kearns, J.R. and Little, B.J. (eds.), ASTM Publications STP 1232, Philadelphia, PA, 1994, p. 61.

[46] Z. Lewandowski, F. Roe, T. Funk and D. Chen, Proc. NSF-CONICET Workshop, Biocorrosion and Biofouling: Metal/Microbe Interactions, Buckman Laboratories International, Inc., Memphis, TN, 1993, p. 52.

[47] P.A. Wagner, B.J. Little, R.I. Ray and J. Jones-Meeham, Corrosion/92, NACE International, Houston, TX, paper No. 185, 1992.

[48] A. Steele, D.T. Goddard and I.B. BeECH, Int. Biodet. Biodegrad. 34 (1) (1994) 35-46.

[49] A. Steele, I.B. Beech and D.T. Goddard, Proc. 1995 International Conference on Microbialy Influenced Corrosion, American Welding Society-NACE International, Houston, TX, 1995, p. 73.

[50] J.W. COSTERTON, Biofouling and Biocorrosion in Industrial Water Systems, Geesey, G.G., Lewandowski, Z. and Flemming, H.C. (eds.), Lewis Publishers, Boca Raton, FL, 1994, p. 1.

[51] Z. LEWANdOWSKI, P. StOOdLEY and F. ROE, Corrosion/95, NACE International, Houston, TX, paper No. 222, 1995.

[52] D.E. Caldwell, D.R. Korber and J.R. Lawrence, Adv. Microbial Ecol. 12 (1992) 1.

[53] H.A. Videla, Manual of Biocorrosion, Chapter 4, Boca Raton, Florida: CRC Lewis Publishers, 1996, p. 73. 